\title{
Hodgkin's disease and the Epstein-Barr virus
}

\author{
K J Flavell, P G Murray
}

\begin{abstract}
Hodgkin's disease is an unusual cancer because the malignant cells constitute only a minority of the total tumour mass and, as a consequence, the study of these cells has been a major challenge. Recently, the application of newer technologies, such as single cell polymerase chain reaction (PCR) and gene expression array analysis, to the study of Hodgkin's disease have yielded new insights into the pathogenesis of this tumour. In addition, the recognition that a proportion of Hodgkin's disease tumours harbour the EpsteinBarr virus (EBV) and that its genome is monoclonal in these tumours suggests that the virus contributes to the development of Hodgkin's disease in some cases. This review summarises current knowledge of the pathogenesis of Hodgkin's disease with particular emphasis on the association with EBV.

(F Clin Pathol: Mol Pathol 2000;53:262-269)
\end{abstract}

Keywords: Hodgkin's disease; Epstein-Barr virus; Hodgkin-Reed Sternberg cells

The histological expression of Hodgkin's disease is diverse. The varied patterns in cellular make up and nodal architecture have caused difficulty in the diagnosis and classification of the disease, and there have been numerous histological classification systems. The first was proposed by Rosenthal in 1936, ${ }^{1}$ and was based on the observation that prognosis for patients with Hodgkin's disease is related to the number of lymphocytes in tissue sections of their tumours. Other systems proposed after Rosenthal's initial work included Jackson and Parker's in $1944^{2}$ and Lukes and Butler's in $1966,{ }^{3}$ the latter being modified at the Rye conference. ${ }^{4}$ The Rye modification of the Lukes and Butler classification divides Hodgkin's disease into four histological subtypes: lymphocyte predominance (LP), nodular sclerosis (NS), mixed cellularity (MC), and lymphocyte depletion (LD). The more recent revised European American lymphoma (REAL) classification ${ }^{5}$ identifies LP, NS, MC, $\mathrm{LD}$, and a provisional entity known as lymphocyte rich classic Hodgkin's disease.

The diagnostic lesion of Hodgkin's disease is characterised by the disruption of normal lymph node architecture and the presence of a minority, usually less than $1-2 \%$ of the total tumour mass, of malignant Hodgkin-Reed Sternberg (HRS) cells amid a background of non-neoplastic cell populations. ${ }^{56}$ The typical cellular background comprises $\mathrm{T}$ and $\mathrm{B}$ cells, eosinophils, neutrophils, plasma cells, histiocytes, fibroblasts, and stromal cells, which either surround the HRS cells or accumulate in their close vicinity. ${ }^{5}$ The HRS cells and their reactive neighbouring cells are able to crosstalk via a complex of cytokine and cell contact dependent interactions, and these probably include proliferative and anti-apoptotic signals favouring tumour cell survival and expansion. ${ }^{7}$ The diagnostic separation of the histological subtypes relies on the type and relative proportions of these so called reactive bystander cells, the presence of fibrosis, and the detection of the various morphological variants of HRS cells. $^{5}$

Immunohistological studies and clinical investigations performed in the 1980 s revealed that the subtypes NS, MC, and LD are immunophenotypically and clinically similar to each other but different from the LP subtype. ${ }^{8}{ }^{9}$ This finding is taken into account in the REAL classification, ${ }^{5}$ which categorises the subtypes NS, MC, and LD under the term "classic Hodgkin's disease". The LP subtype is now considered to be a distinct entity because diagnostic HRS cells expressing CD15 or CD30 are rarely encountered, ${ }^{10}$ whereas $\mathrm{B}$ cell markers such as CD20 are regularly expressed by tumour cells. $^{5}$

Origin of the malignant cells in Hodgkin's disease

The relative scarcity of HRS cells within Hodgkin's disease tumours has made their study problematic. Early phenotypic studies suggested lineages related to macrophages or histiocytes, ${ }^{11}$ dendritic cells, ${ }^{12}$ or granulocytes. ${ }^{13}$ However, evidence now supports the idea that the HRS cell originates from either a $\mathrm{B}$ or $\mathrm{T}$ cell. ${ }^{14-18}$

Many recent studies have relied on the use of polymerase chain reaction (PCR) analysis of single HRS cells to provide information on their clonality and potential cell of origin. ${ }^{19}$ Studies investigating the presence of rearranged $\mathrm{V}_{\mathrm{H}}$ genes in individual HRS cells have produced conflicting results. One group detected polyclonality in four patients with LP Hodgkin's disease, ${ }^{20}$ whereas another found monoclonality in patients with the LP, NS, and MC forms of Hodgkin's disease (one patient each). ${ }^{19} \mathrm{~A}$ larger series demonstrated a range of clonality patterns, including monoclonal B cells in three of eight cases of MC Hodgkin's disease, and a mixed monoclonal and polyclonal pattern in an additional three cases. ${ }^{21}$ The remaining patients, including all four with NS, had polyclonal patterns. Similar results were reported by Delabie et $a l^{22}$ who found some cases of NS Hodgkin's disease with a B cell phenotype and polyclonal immunoglobulin heavy chain $(\operatorname{IgH})$ rearrangements. These findings suggested that the evolution of classic 
Hodgkin's disease might involve the progression from polyclonal to monoclonal disease. A study of relapsed patients with classic Hodgkin's disease showed that the same $\operatorname{IgH}$ rearrangements with identical somatic mutations were found from biopsies taken over a period of three years, demonstrating the persistence and dissemination of a clonal tumour cell population. ${ }^{23}$ Further analysis has revealed that HRS cells carry high loads of somatic Ig mutations, indicating that they originate from germinal centre or postgerminal centre B cells. In most cases it was shown that the $\mathrm{V}_{\mathrm{H}}$ gene rearrangements were non-functional, suggesting that HRS cells can bypass apoptosis, which would otherwise eliminate B cells with defectively rearranged Ig genes. $^{24}$

However, using a single cell PCR approach with less risk of contamination, Marafioti et al only detected monoclonal Ig rearrangements in HRS cells, most of which did not disrupt the Ig coding capacity. ${ }^{25}$ This suggests that some of the previous findings of polyclonal populations of HRS cells might have been the result of technical artefacts. In this study, the absence of Ig expression in HRS cells was confirmed by in situ hybridisation, but clearly could not be explained by the presence of crippling mutations.

The absence of Ig gene expression in classic Hodgkin's disease contrasts with results from the analysis of LP Hodgkin's disease, where the tumour cell population often expresses Ig. ${ }^{9}$ Furthermore, there are differences in the nature of IgH mutations between classic and LP Hodgkin's disease. Whereas intraclonal diversity is uncommon in classic Hodgkin's disease it is more frequent in LP Hodgkin's disease, suggesting the presence of ongoing somatic mutations in the LP form but not the classic form of the disease. ${ }^{26}$

Occasionally, Hodgkin's disease tumours express $\mathrm{T}$ cell antigens, including granzyme $\mathrm{B}$ and $\mathrm{T}$ cell intracellular antigen 1 (TIA-1). In some cases, this has been shown to represent aberrant expression of $T$ cell antigens by HRS cells that show evidence of IgH gene rearrangement and are thus assumed to be $\mathrm{B}$ cell in origin. ${ }^{27}$ However, in the same study a single Hodgkin's disease case showed expression of T cell markers and also $\mathrm{T}$ cell receptor (TCR) gene rearrangements, indicating that at least a minority of HRS cells are genuinely of $\mathrm{T}$ cell origin.

Newer technologies have provided the means of global gene expression analysis in HRS cells. Cossman et al used cDNA libraries prepared from single HRS cells of primary tissues to analyse gene expression and compare this to similar libraries derived from germinal centre B cells and dendritic cells. ${ }^{28}$ This study provided further support for a B cell origin for HRS cells, based on the frequent detection of markers such as BL34 and B7.1-CD80, and was also able to identify genes such as the melanoma associated tumour antigen, MAGE$4 \mathrm{a}$, and the transcription factor, Pax-6, not previously known to be expressed in Hodgkin's disease. In the second of such studies, microar- ray analysis identified the interleukin 13 (IL-13) gene to be highly expressed in Hodgkin's disease derived cell lines. ${ }^{29}$ Subsequent in situ hybridisation of lymph node tissue from patients with Hodgkin's disease showed that HRS cells specifically expressed high amounts of IL-13. Although such techniques are powerful and provide the means to identify novel genes expressed in HRS cells, unravelling the role of these genes and their relevance to the biology of Hodgkin's disease will need careful investigation.

\section{Epidemiology of Hodgkin's disease}

In 1966, Brian MacMahon, ${ }^{30}$ reviewing the epidemiology of Hodgkin's disease, identified a bimodal age distribution in the USA, with the first peak of clinical onset occurring between 15 and 34 years, and the second after 50 years of age. Three age periods were distinguished: $0-14,15-34$, and 50 years and above. MacMahon noted that childhood cases of Hodgkin's disease were more common in boys ( $85 \%$ boys, $15 \%$ girls) for children less than 10 years of age. In young adults he hypothesised that the disease was probably infectious in nature, with low infectivity. This was supported by data from some families that had more than one affected member of different ages at the same time $^{31}{ }^{32}$; an excess of cases had also been identified in winter months. ${ }^{33}{ }^{34}$ The peak incidence in young adults was between 25 and 30 years of age, the sex ratio was almost equal at this time, and the disease was associated with high socioeconomic status as defined by the Registrar General. ${ }^{30}$ MacMahon also identified that the disease in the elderly showed increasing incidence with age, a male to female patient ratio of $2: 1$, and epidemiological features similar to other neoplastic diseases, such as chronic lymphatic leukaemia. MacMahon ${ }^{30}$ hypothesised that this pattern was typical of neoplastic disease and was quite distinct from the young adult disease.

Correa and O'Conor ${ }^{35}$ introduced the concept of at least three epidemiological patterns of Hodgkin's disease based upon country of residence. A type I pattern is characterised by relatively high incidence rates in male children, low incidence in the third decade, and a second peak of high incidence in older age groups. The histological subtypes are often those with a less favourable prognosis, usually either MC or LD. This pattern prevails in developing countries.

Type III is the converse of the type I pattern, being characterised by low rates in children and a pronounced initial peak in young adults. The more favourable subtype of NS is common and this pattern is typical of developed countries.

Type II is an intermediate pattern foundfor example, in rural areas of developed countries, and reflects a transition between type I and type III. Correa and O'Conor ${ }^{35}$ interpreted these data as the result of the interplay of environmental and host factors influencing the natural history of a single disease, and likened it to tuberculosis. In underprivileged communities, there are higher rates of tuberculosis in children and the disease presents itself in the more serious pneumonic form. When eco- 
nomic conditions improve, childhood tuberculosis becomes less common and most cases in young adults are of the more benign pulmonary form. This led to the hypothesis that in a given population susceptibility to the agent or agents that cause Hodgkin's disease is related to immunocompetence and host response, the degree of which is, in turn, dependent on environmental and socioeconomic factors. Hence, there is an alternative to the dual aetiology explanation of bimodality; that of a single aetiological process that is affected by variations in host response over age.

Childhood social environment has been suggested to play an important role in influencing the risk of Hodgkin's disease among young adults, ${ }^{36}$ with higher risk being associated with factors that diminish or delay the exposure to infectious agents, such as higher social class, more education, small family size, and early birth order position. These are consistent with a virus induced pathogenesis, with greater risk of Hodgkin's disease occurring with increasing age at infection.

Gutensohn and Cole ${ }^{37}$ likened the epidemiology of Hodgkin's disease in young adults to that of paralytic poliomyelitis in the pre-vaccine era. In both diseases, age of peak incidence is delayed as living conditions improve. For both, increased risk is associated with higher social class and small family size. They suggested that Hodgkin's disease is a rare consequence of a common infection, with the probability of the disease increasing as age at the time of infection increases.

These findings led to the premise that the variation of the bimodal age incidence curve of Hodgkin's disease is related to the age at primary infection with a common virus. As a population moved towards a higher standard of living, an initial early peak among young boys disappeared and produced the characteristic young adult peak. ${ }^{36}$ The data from the study of factors in childhood environment that influence the age of infection are consistent with this idea. The incidence of disease in the older age group varies little between populations and is not associated with social class factors. ${ }^{38}$

Epstein-Barr virus and Hodgkin's disease As early as 1966 MacMahon $^{30}$ proposed that Hodgkin's disease might be caused by an infectious agent. The first evidence that this agent might be Epstein-Barr virus (EBV) was provided by the detection of raised antibody titres to EBV antigens in patients with Hodgkin's disease when compared with patients with other lymphomas ${ }^{39}$ and, further, that these raised values preceded the development of Hodgkin's disease by several years. ${ }^{40}$ In addition, the relative risk of developing Hodgkin's disease in individuals with a history of infectious mononucleosis, relative to those with no previous history, was shown to range between 2.0 and 5.0. ${ }^{36}$ However, antibody titres to other herpesviruses, including human herpesvirus 6 , have been shown to be raised in prediagnostic sera from patients with Hodgkin's disease, ${ }^{41}$ although these antibody titres were higher in EBV negative as opposed to

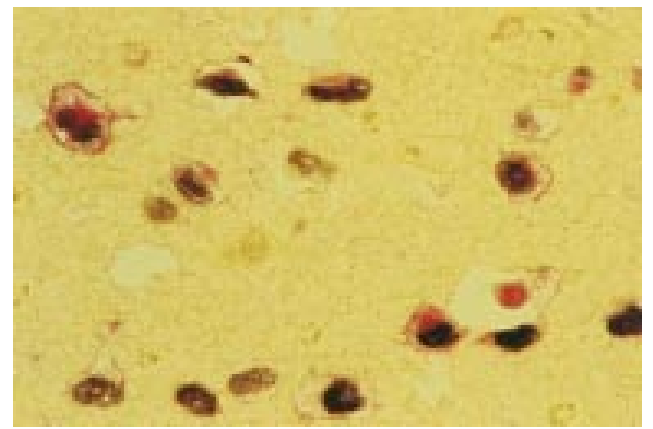

Figure 1 Double labelling of malignant Hodgkin-Reed Sternberg (HRS) cells showing co-expression of Epstein-Barr virus early RNAs (EBERs; brown/black) and latent membrane protein 1 (LMP1; red).

EBV positive cases. ${ }^{42}$ In addition, raised antibody titres to the EBV viral capsid antigen do not predict EBV status in Hodgkin's disease. $^{43}$

EBV could either play a direct or indirect role in the pathogenesis of Hodgkin's disease, possibly by triggering the pathogenic mechanism(s), or it could reflect the presence of an inherited or acquired depression of immunoregulation that is a prelude both to the malignancy and to the reactivation of EBV. ${ }^{44}$ Immunosuppressed patients show rises in all herpesvirus antibodies, rather than a selective rise in EBV antibodies, ${ }^{45}$ which suggests that depression of immunoregulation, rather than a specific disease phenomenon, might be responsible for these raised values.

With the advent of cloned viral probes and Southern blot hybridisation methods, EBV DNA was initially detected in $20-25 \%$ of Hodgkin's disease tumour specimens. ${ }^{46}$ However, this approach could not determine the locality of the EBV genome in tissues. In situ hybridisation methods to detect EBV DNA provided the first demonstration of its existence in the HRS cells. ${ }^{47-49}$ Subsequently, the demonstration of the abundant EBV early RNA (EBER1 and EBER2) sequences in HRS cells provided a sensitive method for detecting latent infection in situ. This technique is generally accepted as the "gold standard" for the detection of latent EBV infection in clinical samples $^{49}$ (fig 1). However several recent studies suggest the existence of another form of latency lacking EBER expression. ${ }^{50} 51$

In Hodgkin's disease, the bulk of viral genomes are found in monoclonal form, indicating that infection of the tumour cells has occurred before their clonal expansion. ${ }^{47} 52$ EBV appears to persist throughout the course of Hodgkin's disease and is also found in multiple sites of Hodgkin's disease. ${ }^{53}$ Furthermore, the EBV genome copy number within HRS cells varies between patients but appears constant within individual patients with Hodgkin's disease. ${ }^{53}$ The inability to detect EBV in all cases of Hodgkin's disease could be the result of the failure to detect genomes present at a low copy number. However, this is unlikely, given the sensitivity and range of assays that have been used. ${ }^{54}$ Another possibility is that EBV transforms Hodgkin's disease progenitor cells by a "hit and run" mechanism, ${ }^{55}$ whereby 
EBV viral DNA rearrangement and loss occurs during malignant progression, similar to that recently suggested for some cases of sporadic Burkitt's lymphoma. However, Staratschek-Jox et al using fluorescence in situ hybridisation analysis found no evidence of integrated EBV genomes in EBV negative Hodgkin's disease tumours. ${ }^{56}$ Therefore, the most likely explanation is that EBV is associated with only a subset of patients.

The association of EBV with Hodgkin's disease seems to depend on factors such as country of residence, histological subtype, sex, ethnicity, and age. In particular, EBV positive Hodgkin's disease tumours appear to be less common in developed populations, with percentages of between $20 \%$ and $50 \%$ for North American and European cases, ${ }^{49}{ }^{57-59} 57 \%$ for Hodgkin's disease in China, ${ }^{60}$ but much higher rates in underdeveloped countries such as Peru $^{61}$ and Kenya. ${ }^{62-64}$ The increased incidence of EBV positive Hodgkin's disease in underdeveloped countries could result from the existence of an underlying immunosuppression similar to that observed for African Burkitt's lymphoma in a malaria infected population. ${ }^{61}$ This is supported by the higher EBV positive rates in Hodgkin's disease from human immunodeficiency virus infected patients. ${ }^{65}$ Alternatively, the timing of EBV infection (which is likely to occur earlier in developing populations) might also be important.

EBV is more commonly associated with the MC subtype and less frequently with the other forms of this disease. ${ }^{5466-68}$ In addition, Hodgkin's disease in the older age group and in children, especially boys under 10 years, has been shown to be more likely to be EBV associated than Hodgkin's disease in young adults. ${ }^{54-70}$ This suggested to Armstrong and colleagues ${ }^{70}$ that Hodgkin's disease consisted of three disease entities: Hodgkin's disease of childhood (EBV positive, MC type), Hodgkin's disease of young adults (EBV negative, NS type), and Hodgkin's disease of older adults (EBV positive, MC type). However, our data ${ }^{71}$ suggest a more homogeneous spread of EBV positive Hodgkin's disease within the adult age ranges defined by Armstrong. One likely explanation for these discrepancies is variation in the composition of Hodgkin's disease subtypes within each age group between studies. The infrequent association of EBV with Hodgkin's disease in young adulthood has also prompted the suggestion that a second virus might be involved, although there is little evidence to support this at present. ${ }^{72}$

Sex and ethnicity are also factors that are related to EBV positivity in Hodgkin's disease. Various studies have shown that EBV positive rates are higher in male patients than in female patients. ${ }^{68}$ In addition, international studies have indicated that EBV positive Hodgkin's disease affects more Asians (predominantly Chinese) and Hispanics than whites or blacks. ${ }^{68}$

Recently, we investigated socioeconomic factors by EBV status in Hodgkin's disease within a small regional population of the UK. Our results showed that higher levels of material deprivation, as determined by the
Townsend score, were more likely in adult patients with EBV positive Hodgkin's disease compared with their EBV negative counterparts. ${ }^{73}$ This relation was particularly evident for female patients and for those with MC disease. Thus, it appears that socioeconomic differences might be responsible, at least in part, for some of the observed geographical variations in EBV positive rates in Hodgkin's disease.

HRS cells exhibit a type II form of latency, EBV gene expression being limited to the EBERs, Epstein-Barr nuclear antigen 1 (EBNA1), ${ }^{74}$ latent membrane protein 1 (LMP1) ${ }^{66}{ }^{67}$ (fig 1), LMP2, ${ }^{75}{ }^{76}$ and the Bam HIA transcripts. ${ }^{75}$ The particularly high level of LMP1 expression in HRS cells ${ }^{66}{ }^{67}$ suggests that the virus is likely to be important in the pathogenesis of EBV associated cases. LMP1 induces many of the phenotypic changes seen in EBV infected B cells, including expression of the $\mathrm{B}$ cell activation markers, CD23 and CD40; IL-10 production; upregulation of cell adhesion molecules such as intercellular adhesion molecule 1 (ICAM-1), lymphocyte function associated antigen 1 (LFA1) and LFA3; and downregulation of CD99. ${ }^{77-79}$ LMP1 also protects B cells from cell death by the upregulation of several anti-apoptosis genes including bcl-2, mcl-1, and A20.80-82 LMP1 functions as a constitutively activated tumour necrosis factor (TNF) receptor and many of the phenotypic and growth transforming effects of LMP1 are the result of its ability to activate a variety of signalling pathways, including nuclear factor $\kappa \mathrm{B}(\mathrm{NF}-\kappa \mathrm{B})$, through two C-terminus activating regions (CTAR1 and CTAR2). ${ }^{83-87}$

In fact, constitutive $\mathrm{NF}-\kappa \mathrm{B}$ activation has been consistently detected in HRS cells, ${ }^{88}$ and nuclear NF- $\mathrm{NB}$ expression can be observed in HRS cells by immunohistochemistry (P Murray, 1999, unpublished data) (fig 2). Inhibition of NF- $\mathrm{KB}$ activity in Hodgkin's disease cell lines leads to their increased sensitivity to apoptosis after growth factor withdrawal and their impaired tumorigenicity in severe combined immunodeficiency (SCID) mice. ${ }^{89} \mathrm{Al}-$ though $\mathrm{NF}-\kappa \mathrm{B}$ activation is a common feature of HRS cells, the molecular routes to this activation may be different between EBV positive and EBV negative Hodgkin's disease. Thus, by single cell PCR of HRS cells, Jungnickel et al detected clonal mutations in the I $\mathrm{B} \alpha$ gene in two of three cases of EBV negative Hodgkin's disease, but no such defects in the two EBV positive cases examined..$^{90}$ This suggests that the constitutive activation of $\mathrm{NF}-\kappa \mathrm{B}$ by LMP1 in EBV positive HRS cells may be substituted by $\mathrm{I} \kappa \mathrm{B} \alpha$ gene mutations in HRS cells not infected by EBV.

Other studies on Hodgkin's disease have failed to show a correlation between LMP1 and the expression of many of the genes known to be upregulated by LMP1 in vitro. For example, BCL-2 protein concentrations do not correlate with LMP1 expression in Hodgkin's disease, ${ }^{91}$ but such a relation has been shown for post-transplant lymphomas. ${ }^{92}$ However, in other situations there is evidence that LMP1 regulated genes are more highly expressed in 


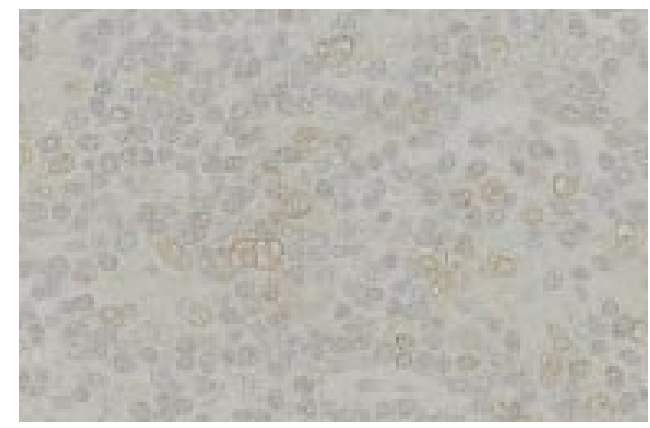

Figure 2 Immunohistochemical detection of nuclear factor $\kappa B(N F-\kappa B)$ in the nuclei of Hodgkin-Reed Sternberg (HRS) cells and other lymphoid cells from Hodgkin's disease using an antibody that recognises the nuclear localisation signal of the p65 subunit of $N F-\kappa B$.

EBV positive, compared with EBV negative Hodgkin's disease, suggesting biologically important differences between the two. For example, IL- $10^{93}$ and IL- $6^{94}$ are more frequently expressed in EBV positive compared with EBV negative Hodgkin's disease. Recent data show that TRAF1, which is upregulated by LMP1 in B cells in vitro is overexpressed in EBV positive Hodgkin's disease. ${ }^{95} 96$

A 30 bp deletion in the BNLF-1 gene, which encodes LMP1, in nude mouse propagated Chinese nasopharyngeal carcinoma (CAO) cells has been observed. CAO LMP1 was found to be more tumorigenic than the prototype B95.8 LMP1. ${ }^{97}$ Initially, this mutation was thought to be preferentially associated with nasopharyngeal carcinoma, but similar mutations have also been detected in some $\mathrm{T}$ cell lymphomas, Hodgkin's disease, infectious mononucleosis, and lymphoblastoid cell lines (LCLs) from healthy controls..$^{98-100}$ Healthy virus carriers have been found to have a similar frequency of mutations to patients with virus infected tumours from the same geographical region. ${ }^{100}$ However, some studies have shown an increased incidence of this deletion variant in HIV positive Hodgkin's disease compared with HIV negative Hodgkin's disease, ${ }^{101}$ and also in paediatric Hodgkin's disease compared with normal controls. ${ }^{102}$

LMP2 is also expressed by HRS cells in EBV associated Hodgkin's disease (fig 3). LMP2A affects signal transduction by obstructing those pathways that are triggered by ligation of the $B$ cell antigen receptor complex (see L S Young et $a l$, this issue). Clustered plasma membrane patches of LMP2A and their N-terminal domains mimic crosslinked receptor tails and become phosphorylated on tyrosine and serine residues. ${ }^{103}$ The LMP2A molecules compete for the binding of the Src family protein tyrosine kinases and the Syk protein tyrosine kinases. This blocks signalling through the $\mathrm{B}$ cell antigen receptor complex and prevents transition of the EBV infected $\mathrm{B}$ cell into the lytic cycle and thus maintains EBV latency. ${ }^{104}$ The precise role of LMP2 in the pathogenesis of Hodgkin's disease, however, remains to be determined.

LMP2, and to a lesser extent LMP1, are targets for cytotoxic $\mathrm{T}$ cells in association with different major histocompatibility complex (MHC) class I restriction elements in

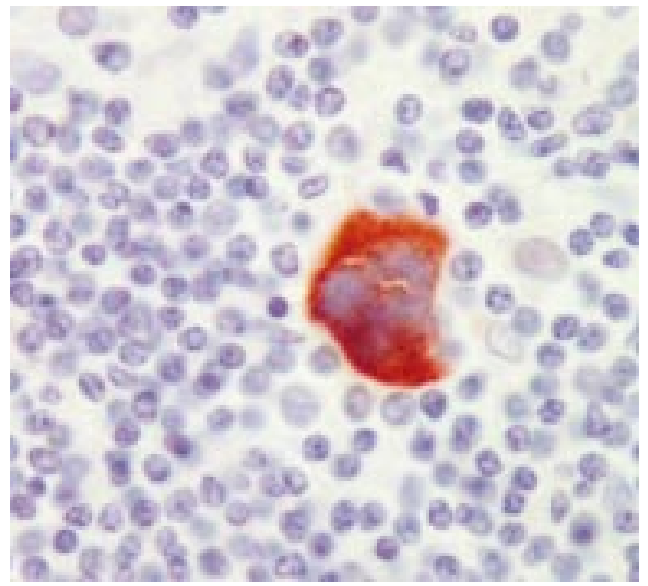

Figure 3 Immunohistochemical detection of latent membrane protein 2 (LMP2) in Hodgkin's disease.

vitro. ${ }^{105-108}$ The survival of EBV infected HRS cells in vivo suggests several possible explanations, including the existence of specific immunological defects present in patients with Hodgkin's disease that permit the growth of the neoplastic cells, ${ }^{52}$ or that EBV infected tumour cells have evolved strategies to evade immunosurveillance. Support for the latter is provided by the finding that IL-10 production is more frequent in EBV infected HRS cells when compared with their EBV negative counterparts, and this has been suggested to account for the failure of these cells to be recognised by EBV specific cytotoxic $\mathrm{T}$ lymphocytes (CTLs). ${ }^{93} 109$ This is further underlined by the observation that tumour derived $\mathrm{T}$ cells from EBV negative Hodgkin's disease show EBV specific cytotoxicity, whereas the corresponding cells from EBV positive Hodgkin's disease lesions do not. ${ }^{110}$ In fact, EBV positive cases of Hodgkin's disease have been shown to contain more activated CTLs and express relatively higher amounts of MHC class I molecules than EBV negative cases. ${ }^{108111112}$ Despite this, there is clearly a failure to elicit an effective anti-EBV CTL response.

One study has shown that the Hodgkin's disease cell line, HDLM2, is able to process and present epitopes from LMP1 and LMP2 in the context of multiple MHC class I alleles, including HLA A2, and is sensitive to lysis by EBV-specific CTLs. ${ }^{113}$ Furthermore, using autologous fibroblasts infected with a vaccinia recombinant encoding LMP2 as a target, the same authors were able to identify and expand LMP2 specific CTLs from the peripheral blood of a patient with Hodgkin's disease. The use of donor derived, EBV specific CTLs has also been investigated in the treatment of EBV positive patients with Hodgkin's disease. ${ }^{114}$ In this study, EBV specific CTLs could be generated from patients with advanced Hodgkin's disease, albeit at lower frequency than normal controls. EBV specific CTLs survived and had antiviral activity in vivo. These results provide some encouragement for the pursuit of CTL treatment for EBV associated Hodgkin's disease. However, further work is required to establish whether the microenvironment of EBV positive HRS cells is likely to compromise 
immunotherapeutic strategies targeted at EBV positive patients with Hodgkin's disease.

In this context, it is interesting that two large studies investigating the influence of EBV infection in Hodgkin's disease have shown improved outcomes for the EBV positive patients compared with their EBV negative counterparts. ${ }^{115116}$ This is somewhat surprising when one considers that the oncogenic LMP1 protein is highly expressed in EBV infected HRS cells, but possible explanations could be that the malignant cells of EBV positive Hodgkin's disease are more sensitive to chemotherapy agents or that the EBV positive cells might be targets for immune cytolysis, particularly after cytoreduction by chemotherapy. The reported higher expression of bcl-2 in EBV negative Hodgkin's disease might suggest greater resistance to chemotherapy induced apoptosis in EBV negative tumours. ${ }^{91}$

\section{Conclusion}

Despite improvements in our understanding of the pathogenesis of Hodgkin's disease the precise contribution of EBV remains largely unknown. Future work to identify the roles of latent virus products, particularly LMP1 and LMP2, is therefore required. Such knowledge is likely to pave the way for greater refinement of EBV targeted gene therapies.

1 Rosenthal SR. Significance of tissue lymphocytes in the prognosis of lymphogranulomatosis. Arch Pathol 1936;21:628-31.

2 Jackson H, Parker F. Hodgkin's disease: II. Pathology. $N$ Engl f Med 1944;231:35-44.

3 Lukes RJ, Butler JJ. The pathology and nomenclature of Lukes RJ, Butler JJ. The pathology and nomen
Hodgkin's disease. Cancer Res 1966;26:1063-81.

4 Lukes RJ, Carver LF, Hall TC, et al. Report of the nomenclature committee in symposium: obstacles to the control of Hodgkin's disease. Cancer Res 1966;26:1311.

5 Harris NL, Jaffe ES, Stein H, et al. A revised EuropeanAmerican classification of lymphoid neoplasms: a proposa from the international lymphoma study group. Blood 1994; 84:1361-92.

6 Drexler HG. Recent results on the biology of Hodgkin and Reed-Sternberg cells. I Biopsy material. Leuk Lymphoma 1992;8:283-313.

7 Pinto A, Gattei V, Zagonel V, et al. Hodgkin's disease: a disorder of dysregulated cellular cross-talk. Biotherapy 1998; 10:309-20.

8 Linden MD, Fishleder AJ, Katzin WE, et al. Absence of B-cell or T-cell clonal expansion in nodular, lymphocyte B-cell or T-cell clonal expansion in nodular, lymphocyte predom.

9 Stoler MH, Nichols GE, Symbula M, et al. Lymphocyte predominance Hodgkin's disease-evidence for a kappa light chain-restricted monotypic B-cell neoplasm. $A m \mathcal{F}$ Pathol 1995;146:812-18.

10 Nicholas DS, Harris S, Wright DH. Lymphocyte predominance Hodgkin's disease - an immunohistochemical study. Histopathology 1990;16:157-65.

11 Kadin M, Stites D, Levy R, et al. Exogenous immunoglobulin and the macrophage origin of the Reed-Sternberg cells in Hodgkin's disease. N Engl F Med 1978;299:1208-14.

12 Curran RL, Jones EL. Hodgkin's disease: an immunohistochemical and histological study. $\mathcal{F}$ Pathol 1978;125:39-51.

13 Stein H, Uchanska-Ziegler B, Gerdes J, et al. Hodgkin and Sternberg-Reed cells contain antigens specific to late Sternberg-Reed cells contain antigens specif
granulopoiesis. Int $\mathcal{F}$ Cancer 1982;29:283-90.

14 Jaffe ES. The elusive Reed-Sternberg cell. $N$ Engl $7 \mathrm{Med}$ 1989;320:529-31.

15 Diehl V, von Kalle C, Fonatsch C, et al. The cell of origin in Hodgkin's disease. Semin Oncol 1990;17:660-72

16 Oudejans JJ, Kummer JA, Jiwa M, et al. Granzyme B expression in Reed-Sternberg cells of Hodgkin's disease. Am $\mathcal{F}$ Pathol 1996;148:233-40.

17 Stein H, Hummel M, Marafioti T, et al. Molecular biology of Hodgkin's disease. Cancer Surv 1997;30:107-23.

18 Foss HD, Reusch R, Demel G, et al. Frequent expression of the B-cell-specific activator protein in Reed-Sternberg cells of classical Hodgkin's disease provides further evidence for its B-cell origin. Blood 1999;94:3108-13.

19 Küppers R, Rajewsky K, Zhao M, et al. Hodgkin disease: Hodgkin and Reed-Sternberg cells picked from histological sections show clonal immunoglobulin gene rearrangements sections show clonal immunoglobulin gene rearrangements
and appear to be derived from B cells at various stages of and appear to be derived from B cells at various stages of
development. Proc Natl Acad Sci U S A 1994;91:10962-6.
20 Delabie J, Tierens A, Wu G, et al. Lymphocyte predominance Hodgkin's disease: lineage and clonality determination using a single-cell assay. Blood 1994;84:3291-8.

21 Hummel M, Ziemann K, Lammert H, et al. Hodgkin's disease with monoclonal and polyclonal populations of ReedSternberg cells. N Engl F Med 1995;333:901-6.

22 Delabie J, Tierens A, Gavriil T, et al. Phenotype, genotype and clonality of Reed-Sternberg cells in nodular sclerosis Hodgkin's disease: results of a single-cell study. $\mathrm{Br} f$ Haematol 1996;94:198-205.

23 Vockerodt $M$, Soares $M$, Kanzler $H$, et al. Detection of clonal Hodgkin and Reed-Sternberg cells with identical somatically mutated and rearranged $\mathrm{V}_{\mathrm{H}}$ genes in different biopsies in relapsed Hodgkin's disease. Blood 1998;92: 2899-907.

24 Kanzler H, Kuppers R, Hansmann ML, et al. Hodgkin and Reed-Sternberg cells in Hodgkin's disease represent the outgrowth of a dominant tumor clone derived from (crippled) germinal center B cells. F Exp Med 1996;184: 1495-505.

25 Marafioti T, Hummel M, Foss H-D, et al. Hodgkin and Reed-Sternberg cells represent an expansion of a single clone originating from a germinal centre B-cell with functional immunoglobulin gene rearrangements but defective immunoglobulin transcription. Blood 2000;95:1443-50.

26 Marafioti T, Hummel M, Anagnostopoulos I, et al. Origin of nodular lymphocyte-predominant Hodgkin's disease from a clonal expansion of highly mutated germinal-center B cells. N Engl f Med 1997;337:453-8.

27 Müschen M, Rajewsky K, Bräuninger A, et al. Rare occurrence of classical Hodgkin's disease as a T cell occurrence of classical Hodgkin's disea
lymphoma. $\mathcal{F}$ Exp Med 2000;191:387-94.

28 Cossman J, Annunziata CM, Barash S, et al. ReedSternberg cell genome expression supports a B-cell lineage. Blood 1999:94:411-16.

29 Kapp U, Yeh W-C, Patterson B, et al. Interleukin 13 is secreted by and stimulates the growth of Hodgkin and Reed-Sternberg cells. F Exp Med 1999;189:1939-46.

30 MacMahon B. Epidemiology of Hodgkin's disease. Cancer Res 1996;26:1189-200.

31 Devore JW, Doan CA. Studies in Hodgkin's syndrome. XII. Hereditary and epidemiologic aspects. Ann Intern Med 1957;47:300-16.

32 Razis DV, Diamond HD, Craver LF. Familial Hodgkin's disease: its significance and implications. Ann Intern Med 1959;51:933-71.

33 Cridland MD. Seasonal incidence of clinical onset of Hodgkin's disease. BMF 1961;2:621-3.

34 Fraumeni JF, Jr, Li FP. Hodgkin's disease in childhood: an epidemiologic study. $\mathscr{F}$ Natl Cancer Inst 1969;42:681-91.

35 Correa P, O'Conor GT. Epidemiologic patterns of Hodgkin's disease. Int $\mathcal{F}$ Cancer 1971;8:192-201.

36 Gutensohn N, Cole P. Epidemiology of Hodgkin's disease. Semin Oncol 1980;7:92-102.

37 Gutensohn N, Cole P. Childhood social environment and Hodgkin's disease. $N$ Engl f Med 1981;304:135-40.

38 Gutensohn NM. Social class and age at diagnosis of Hodgkin's disease; new epidemiologic evidence on the "twodisease" hypothesis. Cancer Treat Rep 1982;66:689-95.

39 Levine PH, Ablashi DV, Berard CW, et al. Elevated antibody titers to Epstein-Barr virus in Hodgkin's disease. Cancer $1971 ; 27: 416-21$.

40 Mueller N, Evans A, Harris NL, et al. Hodgkin's disease and Epstein-Barr virus: altered antibody pattern before diagnosis. N Engl f Med 1989;320:689-95.

41 Clark DA, Alexander FE, McKinney PA, et al. The sero-epidemiology of human herpes virus-6 (HHV-6) from a Yorkshire case-control study of leukaemia and lymphoma. Int $\mathcal{f}$ Cancer 1990;45:829-33.

42 Alexander FE, Daniel CP, Armstrong AA, et al. Case clustering, Epstein-Barr virus Reed-Sternberg cell status and herpes virus serology in Hodgkin's disease: results of a and herpes virus serology in Hodgkin's disease: results

43 Levine PH, Pallesen G, Ebbesen P, et al. Evaluation of Epstein-Barr virus antibody patterns and detection of viral markers in the biopsies of patients with Hodgkin's disease. Int $\mathcal{F}$ Cancer 1994;59:48-50.

44 Evans AS, Gutensohn NM. A population-based case control study of EBV and other viral antibodies among persons with Hodgkin's disease and their siblings. Int $\mathcal{f}$ Cancer 1984;34:149-57.

45 Armstrong JA, Evans AS, Rao N, et al. Viral infection in renal transplant recipients. Infect Immun 1976;14:970-5.

46 Weiss LM, Strickler JG, Warnke RA, et al. Epstein-Barr viral DNA in tissues of Hodgkin's disease. Am $\mathcal{f}$ Pathol 1987;129:86-91.

47 Anagnostopoulos I, Herbst H, Niedobitek G, et al. Demonstration of monoclonal EBV genomes in Hodgkin's disease and $\mathrm{Ki}-1$ positive anaplastic large cell lymphoma by combined Southern blot and in situ hybridization. Blood 1989;74:810-16.

48 Weiss LM, Movahed LA, Warnke RA, et al. Detection of Epstein-Barr viral genomes in Reed-Sternberg cells of Hodgkin's disease. N Engl f Med 1989;320:502-6.

49 Wu TC, Mann RB, Charache P, et al. Detection of EBV gene expression in Reed-Sternberg cells of Hodgkin's disease. Int $\mathcal{F}$ Cancer 1990;46:801-4.

50 Bonnet M, Guinebretiere J-M, Kremmer E, et al. Detection of Epstein-Barr virus in invasive breast cancers. 7 Natl Cancer Inst 1999;91:1376-81.

51 Sugawara Y, Mizugaki Y, Uchida T, et al. Detection of Epstein-Barr virus (EBV) in hepatocellular carcinoma tissue: a novel EBV latency characterized by the absence of 
EBV-encoded small RNA expression. Virology 1999;256: 196-202.

52 Herbst H, Niedobitek G. Epstein-Barr virus and Hodgkin's disease. Int f Clin Lab Res 1993;23:13-16.

53 Coates PJ, Slavin G, D’Ardenne AJ. Persistence of EpsteinBarr virus in Reed-Sternberg cells throughout the course of Hodgkin's disease. F Pathol 1991;164:291-7.

54 Jarrett AF, Armstrong AA, Alexander E. Epidemiology of EBV and Hodgkin's lymphoma. Ann Oncol 1996;7(suppl 4):S5-10.

55 Razzouk BI, Srinivas S, Sample CE, et al. Epstein-Barr virus DNA recombination and loss in sporadic Burkitt's lymphoma. F Infect Dis 1996;173:529-35.

56 Staratschek-Jox A, Kotkowski S, Belge G, et al. Detection of Epstein-Barr virus in Hodgkin-Reed-Sternberg cells: no evidence for the persistence of integrated viral fragments in latent membrane protein-1 (LMP-1)-negative classical latent membrane protein-1 (LMP-1)-negative

57 Weiss LM, Chen Y-Y, Liu X-F, et al. Epstein-Barr virus and Hodgkin's disease: a correlative in situ hybridization and Hodgkin's disease: a correlative in situ hybridization and polymerase

58 Herbst H, Steinbrecher E, Niedobitek G, et al. Distribution and phenotype of Epstein-Barr virus-harboring cells in Hodgkin's disease. Blood 1992;80:484-91.

59 Hummel M, Anagnostopoulos I, Dallenbach F, et al. EBV infection patterns in Hodgkin's disease and normal lymphoid tissue: expression and cellular localization of gene products. Br F Haematol 1992;82:689-94.

60 Zhou X-G, Hamilton-Dutoit SJ, Yan Q-H, et al. The association between Epstein-Barr virus and Chinese Hodgkin's disease. Int $\mathcal{f}$ Cancer 1993;55:359-63.

61 Chang KL, Albujar PF, Chen Y-Y, et al. High prevalence of Epstein-Barr virus in the Reed-Sternberg cells of Hodg-

62 Leoncini L, Spina D, Nyong'o A, et al. Neoplastic cells of Hodgkin's disease show differences in EBV expression between Kenya and Italy. Int f Cancer 1996;65:781-4.

63 Weinreb M, Day PJR, Niggli F, et al. The consistent association between Epstein-Barr virus and Hodgkin's disease in children in Kenya. Blood 1996;87:3828-36.

64 Weinreb M, Day PJR, Niggli F, et al. The role of Epstein-Barr virus in Hodgkin's disease from different geographical areas. Arch Dis Child 1996;74:27-31.

65 Uccini S, Monardo F, Stoppacciaro A, et al. High frequency of Epstein-Barr virus-genome detection in Hodgkin's disease of HIV-positive patients. Int f Cancer 1990;46:5815 .

66 Pallesen G, Hamilton-Dutoit SJ, Rowe M, et al. Expression of Epstein-Barr virus latent gene products in tumour cells

67 Murray PG, Young LS, Rowe M, et al. Immunohistochemical demonstration of the Epstein-Barr virus-encoded chemical demonstration of the Epstein-Barr virus-encoded disease. F Pathol 1992;166:1-5.

68 Glaser SL, Lin RJ, Stewart SL, et al. Epstein-Barr virus-associated Hodgkin's disease: epidemiologic characteristics in international data. Int $\mathcal{F}$ Cancer 1997;70:375-82.

69 Jarrett RF, Gallagher A, Jones DB, et al. Detection of Epstein-Barr virus genomes in Hod
to age. $\mathcal{F}$ Clin Pathol 1991;44:844-8.

70 Armstrong AA, Alexander FE, Cartwright R, et al. EpsteinBarr virus and Hodgkin's disease: further evidence for the three disease hypothesis. Leukemia 1998;12:1272-6.

71 Flavell KJ, Biddulph JP, Constandinou CM, et al. Variation in the frequency of Epstein-Barr virus-associated Hodgin the frequency of Epstein-Barr virus-associated
kin's disease with age. Leukemia 2000;14:748-53.

72 Armstrong AA, Shield L, Gallagher A, et al. Lack of involvement of known oncogenic DNA viruses in Epstein-Barr
virus-negative Hodgkin's disease. Br $\mathcal{f}$ Cancer 1998;77: virus-negat. $1045-7$.

73 Flavell K, Constandinou C, Lowe D, et al. Effect of material deprivation on Epstein-Barr virus infection in Hodgkin's disease in the West Midlands. Br f Cancer 1999;80:604-8

74 Grässer FA, Murray PG, Kremmer E, et al. Monoclonal antibodies directed against the Epstein-Barr virus-encoded nuclear antigen 1 (EBNA 1): immunohistologic detection of EBNA 1 in the malignant cells of Hodgkin's disease. Blood 1994;84:3792-8.

75 Deacon EM, Pallesen G, Niedobitek G, et al. Epstein-Barr virus and Hodgkin's disease: transcriptional analysis of virus latency in the malignant cells. $\mathcal{F}$ Exp Med 1993;177: 339-49.

76 Niedobitek G, Kremmer E, Herbst H, et al. Immunohistochemical detection of the Epstein-Barr virus-encoded latent membrane protein $2 \mathrm{~A}$ in Hodgkin's disease and latent membrane protein 2A in Hodgkin's dise

77 Wang F, Gregory C, Sample C, et al. Epstein-Barr virus latent membrane protein (LMP1) and nuclear proteins 2 and 3C are effectors of phenotypic changes in B CD23. F Virol 1990;64:2309-18

78 Nakagomi H, Dolcetti R, Bejarano MT, et al. The EpsteinBarr-virus latent membrane protein-1 (LMP1) induces interleukin-10 production in Burkitt-lymphoma lines. Int $f$ Cancer 1994;57:240-4.

79 Kim SH, Shin YK, Lee I-S, et al. Viral latent membrane protein 1 (LMP-1)-induced CD99 down-regulation in B cells leads to the generation of cells with Hodgkin's and Reed-Sternberg phenotype. Blood 2000;95:294-300.

80 Henderson S, Rowe M, Gregory C, et al. Induction of bcl-2 expression by Epstein-Barr virus latent membrane protein
1 protects infected B cells from programmed cell death. Cell 1991;65:1107-15.
81 Laherty CD, Hu HM, Opipari AW, et al. The Epstein-Barr virus LMP1 gene product induces A20 zinc finger protein expression by activating nuclear factor kappa B. $\mathcal{F}$ Biol Chem 1992;267:24157-60.

82 Wang S, Rowe M, Lundgren E. Expression of the Epstein Barr virus transforming protein LMP1 causes a rapid and transient stimulation of the Bcl-2 homologue Mcl-1 levels in B-cell lines. Cancer Res 1996;56:4610-13.

83 Rowe M, Peng-Pilon M, Huen DS, et al. Upregulation of bcl-2 by the Epstein-Barr virus latent membrane protein LMP1: a B-cell-specific response that is delayed relative to NF-kappa B activation and to induction of cell surface markers. F Virol 1994;68:5602-12.

84 Herrero JA, Mathew P, Paya CV. LMP-1 activates NF-kappa B by targeting the inhibitory molecule I kappa B alpha. F Virol 1995;69:2168-74.

85 Huen DS, Henderson SA, Croom-Carter D, et al. The Epstein-Barr virus latent membrane protein-1 (LMP1) mediates activation of NF-kappa B and cell surface phenotype via two effector regions in its carboxy-terminal cytoplasmic domain. Oncogene 1995;10:549-60.

86 Mitchell T, Sugden B. Stimulation of NF-kappa B-mediated transcription by mutant derivatives of the latent membrane protein of Epstein-Barr virus. F Virol 1995;69:2968-76.

87 Mosialos G, Birkenbach M, Yalamanchili R, et al. The Epstein-Barr virus transforming protein LMP1 engages signaling proteins for the tumor necrosis factor receptor family. Cell 1995;80:389-99.

88 Bargou RC, Leng C, Krappmann D, et al. High-level

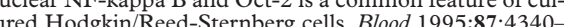
7.

89 Bargou RC, Emmerich F, Krappmann D, et al. Constitutive nuclear factor-kappaB-RelA activation is required for proliferation and survival of Hodgkin's disease tumor cells. $\mathcal{F}$ Clin Invest 1997;100:2961-9.

90 Jungnickel B, Staratschek-Jox A, Bräuninger A, et al. Clonal deleterious mutations in the I $\mathrm{B} \alpha$ gene in the malignant cells in Hodgkin's lymphoma. F Exp Med 2000;191:395401.

91 Khan G, Gupta RK, Coates PJ, et al. Epstein-Barr virus infection and bcl-2 proto-oncogene expression: separate events in the pathogenesis of Hodgkin's disease? Am Pathol 1993;143:1270-4.

92 Murray PG, Swinnen LJ, Constandinou CM, et al. BCL-2 but not its Epstein-Barr virus-encoded homologue, BHRF1, is commonly expressed in posttransplantation lymphoproliferative disorders. Blood 1996;87:706-11.

93 Herbst H, Foss HD, Samol J, et al. Frequent expression of interleukin-10 by Epstein-Barr virus-harboring tumor cells of Hodgkin's disease. Blood 1996;87:2918-29.

94 Herbst H, Samol J, Foss HD, et al. Modulation of interleukin-6 expression in Hodgkin and Reed-Sternberg interleukin-6 expression in Hodgkin and Reed-Sternber cells by Epstein-Barr virus. F Pathol 1997,182:29-306.

95 Durkop H, Foss HD, Demel G, et al. Tumor necrosis factor receptor-associated factor 1 is overexpressed in ReedSternberg cells of Hodgkin's disease and Epstein-Barr virus-transformed lymphoid cells. Blood 1999;93:617-23.

96 Murray PG, Flavell JR, Lowe D, et al. Expression of the tumor necrosis factor receptor-associated factors- 1 and -2 in Hodgkin's disease. F Pathol [In press.]

$97 \mathrm{Hu} \mathrm{LF}$, Chen F, Zheng X, et al. Clonability and tumorigenicity of human epithelial cells expressing the EBV encoded membrane protein LMP1. Oncogene 1993;8: 1575-83.

98 Knecht H, Bachmann E, Brousset P, et al. Deletions within the LMP1 oncogene of Epstein-Barr virus are clustered in Hodgkin's disease and identical to those observed in nasopharyngeal carcinoma. Blood 1993;82:2937-42.

99 Sandvej K, Peh SC, Andresen BS, et al. Identification of potential hot spots in the carboxy-terminal part of the Epstein-Barr virus (EBV) BNLF-1 gene in both malignant and benign EBV-associated diseases: high frequency of a 30 bp deletion in Malaysian and Dan
lymphomas. Blood 1994;84:4053-60.

00 Khanim F, Yao Q-Y, Niedobitek G, et al. Analysis of Epstein-Barr virus gene polymorphisms in normal donors and in virus-associated tumors from different geographic locations. Blood 1996;88:3491-501.

101 Bellas C, Santon A, Manzanal A, et al. Pathological, immunological, and molecular features of Hodgkin's disease associated with HIV infection in comparison with ordinary Hodgkin's disease. Am f Surg Pathol 1996;20: 1520-4.

102 Santon A, Martin C, Manzanal AI, et al. Paediatric Hodgkin's disease in Spain: association with Epstein-Barr virus strains carrying latent membrane protein-1 oncogene deletions and high frequency of dual infections. Br F Haematol 1998;103:129-36.

103 Panousis CG, Rowe DT. Epstein-Barr virus latent membrane protein 2 associates with and is a substrate for mitogen-activated protein kinase. F Virol 1997;71:4752-60.

104 Brielmeier M, Mautner J, Laux G, et al. The latent membrane protein 2 gene of Epstein-Barr virus is important for efficient B cell immortalization. F Gen Virol 1996;77:280718.

105 Rickinson AB, Moss DJ, Allen DJ, et al. Reactivation of Epstein-Barr virus specific cytotoxic $\mathrm{T}$ cells by in vitro stimulation with the autologous lymphoblastoid cell line. Int f Cancer 27:593-601.

106 Thorley-Lawson DA, Israelsohn ES. Generation of specific cytotoxic T cells with a fragment of the Epstein-Barr virusencoded p63/latent membrane protein. Proc Natl Acad Sci US A 1987;84:5384-8. 
107 Khanna R, Burrows SR, Nicholls J, et al. Identification of cytotoxic T cell epitopes within Epstein-Barr virus (EBV) Oncogene latent membrane protein 1 (LMP1): evidence for infected cells by LMP1-specific cytotoxic T lymphocytes. infected cells by LMP1-specific

108 Lee SP, Constandinou CM, Thomas WA, et al. Antigen presenting phenotype of Hodgkin Reed-Sternberg cells: analysis of the HLA class I processing pathway and the effects of interleukin-10 on Epstein-Barr virus-specific cytotoxic T-cell recognition. Blood 1998;92:1020-30.

109 Dukers DF, Jaspars LH, Vos W, et al. Quantitative immunohistochemical analysis of cytokine profiles in Epstein-Barr virus-positive and -negative cases of Hodgkin's disease. F Pathol 2000;190:143-9.

110 Frisan T, Sjoberg J, Dolcetti R, et al. Local suppression of Epstein-Barr virus (EBV)-specific cytotoxicity in biopsies of EBV-positive Hodgkin's disease. Blood 1995;86:1493501 .

111 Oudejans JJ, Jiwa NM, Kummer JA, et al. Analysis of major histocompatibility complex class I expression on ReedSternberg cells in relation to the cytotoxic T-cell response in Epstein-Barr virus-positive and -negative Hodgkin's disease. Blood 1996;87:3844-51.
112 Murray PG, Constandinou CM, Crocker J, et al. Analysis of major histocompatibility complex class I, TAP expression, and LMP2 epitope sequence in Epstein-Barr virus-positive Hodgkin's disease. Immunity to EBV in healthy virus carriers. Blood 1998;92:2477-83.

113 Sing AP, Ambinder RF, Hong DJ, et al. Isolation of Epstein-Barr virus (EBV)-specific cytotoxic T lymphocytes that lyse Reed-Sternberg cells: implications for immunemediated therapy of EBV+ Hodgkin's disease. Blood 1997; 89:1978-86.

114 Roskrow MA, Suzuki N, Gan Yj, et al. Epstein-Barr virus (EBV)-specific cytotoxic T lymphocytes for the treatment of patients with EBV-positive relapsed Hodgkin's disease. Blood 1998;91:2925-34.

115 Morente MM, Piris MA, Abraira V, et al. Adverse clinical outcome in Hodgkin's disease is associated with loss of retinoblastoma protein expression, high Ki67 proliferation index, and absence of Epstein-Barr virus-latent membrane protein 1 expression. Blood 1997;90:2429-36.

116 Murray PG, Billingham LJ, Hassan HT, et al. Effect of Epstein-Barr virus infection on response to chemotherapy and survival in Hodgkin's disease. Blood 1998;94:442-7.

\section{Fournal of Clinical Pathology - http://www.molpath.com}

Visitors to the world wide web can now access the fournal of Clinical Pathology either through the BMJ Publishing Group's home page (http://www.bmjpg.com) or directly by using its individual URL (http://www.molpath.com). There they will find the following:

- Current contents list for the journal

- Contents lists of previous issues

- Members of the editorial board

- Information for subscribers

- Instructions for authors

- Details of reprint services.

A hotlink gives access to:

- BMJ Publishing Group home page

- British Medical Association web site

- Online books catalogue

- BMJ Publishing Group books.

The web site is at a preliminary stage and there are plans to develop it into a more sophisticated site. Suggestions from visitors about features they would like to see are welcomed. They can be left via the opening page of the BMJ Publishing Group site or, alternatively, via the journal page, through "about this site". 